\title{
Selenium and nano-selenium ameliorations in two breeds of broiler chickens exposed to heat stress
}

\author{
R.A. Hassan ${ }^{1}$, E.S. Soliman ${ }^{2 \#}$, R.T. Hamad ${ }^{3}$, O.M. El-Borady ${ }^{4}$, A.A. Ali ${ }^{5}$ \& M.S. Helal ${ }^{6}$ \\ ${ }^{1}$ Animal Production Division, Department of Animal Wealth Development, Faculty of Veterinary Medicine, Suez Canal \\ University, Ismailia, Egypt, 41522 \\ ${ }^{2}$ Animal, Poultry and Environmental Hygiene Division, Department of Animal Hygiene, Zoonosis, and Animal Behavior, \\ Faculty of Veterinary Medicine, Suez Canal University, Ismailia, Egypt, 41522 \\ ${ }^{3}$ Department of Pathology, Faculty of Veterinary Medicine, Menoufia University, Al Minufya, Egypt, 32511 \\ ${ }^{4}$ Institute for Nanoscience and Nanotechnology, Kafrelsheikh University, Kafrelsheikh, Egypt, 33511 \\ ${ }^{5}$ Animal Behavior and Management Division, Department of Animal Hygiene, Zoonosis, and Animal Behavior, Faculty of \\ Veterinary Medicine, Suez Canal University, Ismailia, Egypt, 41522 \\ ${ }^{6}$ Reference Laboratory for Veterinary Quality Control on Poultry Production, Ismailia, Egypt, 41513
}

(Received 22 August 2019; Accepted 29 December 2019; First published online 10 April 2020)

\begin{abstract}
Copyright resides with the authors in terms of the Creative Commons Attribution 4.0 South African License.
See: http://creativecommons.org/licenses/by/4.0/za

Condition of use: The user may copy, distribute, transmit and adapt the work, but must recognize the authors and the South African Journal of Animal Science.
\end{abstract}

\begin{abstract}
The objective of this study was to compare the effects of synthesized nano-selenium (NS) and commercial inorganic selenium (Se) on immunity, behaviour, and performance of Arbor (AB) and Ross (RB) broilers that were exposed to heat stress of $40^{\circ} \mathrm{C}$ for $6-8$ hours daily over 38 days. Two hundred and ten one-day-old broilers of two breeds were supplemented with $0.5 \mathrm{~mL} / \mathrm{L}$ of $\mathrm{NS}$ or Se in their drinking water. Two hundred sera, 200 intestinal swabs, and 1000 internal organ and tissue samples were collected. Weight gain, performance index, behavioral indices, total antioxidant capacity, malondialdehyde, superoxide dismutase, immunoglobulin $\mathrm{G}$, immunoglobulin $\mathrm{M}$, serum total protein, albumin, alanine aminotransferase, aspartate aminotransferase, and serum creatinine concentrations increased $(P<0.01)$ in RB compared with AB when supplemented with NS. Meanwhile, NS supplementation decreased $(P<0.01)$ water intake and the logarithmic bacterial counts of the intestine and breast in $R B$ and $A B$, respectively. Histopathology revealed mild leukocytic infiltration and mild vacuolar degeneration in hepatocytes, and focal leukocytic infiltration, mild congestion, and cytoplasmic vacuolation in the myocardium of RB. Photomicrographs showed a mild lymphoid depletion in the spleen, while histopathology of the bursa of Fabricius revealed a normal follicular epithelium and normal lymphoid follicles with mild inter-follicular fibrosis in RB that were supplied with NS as opposed to $A B$, which expressed more severe pathological affections from heat stress. Thus, NS was more effective than Se in allowing broilers to respond to heat stress.
\end{abstract}

Keywords: behaviour, immunity, growth traits, tissue architecture

\#Corresponding author: soliman.essam@vet.suez.edu.eg

\section{Introduction}

The poultry industry has expanded worldwide owing to increased demands for chicken meat and eggs. Research, as a result of industry growth, has led to improved growth rate, feed efficiency, health status, and reduced carriage of pathogens. However, the research focus has been on enhanced productivity. Vitamin and mineral supplements are used to maintain rapid growth and improve the feed conversion ratio (FCR) and thus lower the amount of feed that is needed to attain market weight (Zhao et al., 2017). Essential elements, which include iron, zinc, chromium, manganese, Se, and molybdenum, are vital to the health of poultry and play important roles in the function of co-enzymes (Peters et al., 2016). Selenium can be supplemented in poultry rations in organic forms (selenomethionine), which have been found to be more suitable than inorganic forms (selenite), which are less efficient (Bolea-Fernandez et al., 2017). Optimum Se concentrations in the ration are essential to good performance and preservation of meat quality during storage (Markovic et al., 2018). Selenium-yeast supplementation of laying Japanese quail also improved the Haugh unit and significantly influenced eggshell and egg quality characteristics (Baylan et al., 2015). 
Nanoparticles are highly absorbable and can augment vaccines and nutrient supplements because of their large surface area to volume ratio and minimal energy loss. Nanoparticles can carry compounds to target organs or systems directly, while avoiding the rapid degradation that has been observed with some antibiotics. Thus, they may provide health benefits (Gangadoo et al., 2016). For example, NS has been considered a potential supplement for broilers as it possesses low toxicity, high catalytic efficiency, and antibacterial activity (Wadhwani et al., 2016; Skalickova et al., 2017).

Heat stress challenges the immune, hormonal, and metabolic systems in broilers (Lara \& Rostagno, 2013). During heat stress, thyroid hormones and feed intake (FI) have been shown to be greatly reduced, with blood flowing preferentially to the skin in an attempt to dissipate heat (Gu et al., 2012). Further, intestinal integrity is greatly reduced, allowing enteric pathogens to enter the systemic circulation and thus increase the opportunity for infection (Gu et al., 2012). Under heat stress, broilers express higher levels of seleno-protein with a consequent increase in the requirement for Se. Further, Se can aid in maintaining efficient antioxidant defence mechanisms and minimize or prevent the fatal consequences of heat stress (Surai et al., 2018).

The aim of this study was to investigate the influence of synthesized NS and inorganic Se, which were provided at rate of $0.5 \mathrm{ml}$ of $100 \mathrm{mg} / \mathrm{L}$ per litre of drinking water on Ross and Arbor (Aviagen, Inc. Huntsville, Alabama, USA) broilers when they were exposed to heat stress at $40^{\circ} \mathrm{C}$ for 6 - 8 hours daily for 38 days. The comprehensive characterization of these effects included monitoring growth, water intake, behaviour patterns, total bacterial and Enterobacteriaceae counts of the intestine and breast muscle, serum biochemical parameters, immunoglobulin concentrations (IgG and $\operatorname{lgM}$ ), and histopathological characteristics of heart, liver, spleen, and bursa.

\section{Material and Methods}

The protocols that were used in this study were approved by the Scientific Research Ethics Committee, Faculty of Veterinary Medicine, Suez Canal University, Egypt (approval number 2018062).

Two hundred and ten one-day-old Arbor and Ross chicks were purchased from the hatchery at Ismailia, Egypt. Birds were housed in a deep litter system (hay). Litter was treated with superphosphate (0.5 $\mathrm{g} / \mathrm{m}^{-2}$ ) to minimize ammonia evaporation and microbial survival according to Soliman et al. (2018). Birds were divided into three groups per breed with each group consisting of 35 chicks. The groups were further divided into five replicates of seven birds, and housed in separate isolated rooms with low thermal conduction ( $\mathrm{K}$ value) and thermal transmission ( $\mathrm{U}$ value).

Birds were initially brooded at $35^{\circ} \mathrm{C}$ with a $0.5^{\circ} \mathrm{C}$ daily decrease in temperature until $21-25^{\circ} \mathrm{C}$ was achieved by the third week. Natural ventilation aids were available in the rooms as $\mathrm{V}$-shaped windows using natural convection. Continuous lightning (23 hours light and 1 hour darkness) was provided with white LED lights as recommended by Soliman and Hassan (2019). The broilers were given ad libitum access to water and provided with a nutritionally balanced standard soybean diet (NRC, 1994). The rations consisted of about $23 \%$ protein and $3000 \mathrm{kcal} / \mathrm{kg}$ energy in the starter ration, which was provided in the first fourteen days of life, and $21 \%$ protein and $3100 \mathrm{kcal} / \mathrm{kg}$ in the grower ration, which was provided for the remainder of the experiment (24 days). The experiment was designed to last for 38 days. Mortality of the birds, temperature and relative humidity were monitored and recorded daily. Birds received attenuated live infectious bronchitis virus vaccine (IB-H120 $\geq 10^{3.5} \mathrm{EID}_{50} /$ dose) on day 6 , attenuated live Infectious bursal disease virus vaccine (VMG91 $\geq 10^{3.0} \mathrm{TCID}_{50}$ ) on days 13 and 21 and lentogenic Newcastle disease virus vaccine (Lasota $\geq 10^{6.0}$ EID $\left.{ }_{50}\right)$ on days 18 and 26 in de-chlorinated drinking water.

Sodium sulphate and Se powder were refluxed and heated at $70{ }^{\circ} \mathrm{C}$ for 6 hours according to Gorer and Hodes (1994) to produce a sodium seleno-sulphate solution. Filtration of the solution followed by adding glucose $6 \%$ powder as stabilizing and reducing agent and polyvinyl alcohol to prevent deviations in morphological characters of NS, and protection from aggregation. The solution was refluxed for an additional six hours to develop a pale-yellow colour, which indicated a final stable product. The synthesized NS was examined and identified using transmission electron microscopy and a UV-visible double beam spectrophotometer. Synthesized NS and commercial Se $(100 \mathrm{mg} / \mathrm{L})$ were provided to the groups of broilers in their drinking water. The groups of Arbor broilers were designated G1, G2, and G3 and the groups of Ross broilers were designated G4, G5, and G6. Treatments were assigned to the groups as follows: G1 and G4 were supplemented with NS, G2, and G5 were supplemented with Se, and G3 and G6 were controls. Four of the six groups (G1, G2, G4, and G5) were subjected to heat stress at $40{ }^{\circ} \mathrm{C}$ for $6-8$ hours daily using heaters. Behaviour and water intake were monitored during periods of exposure.

A total of 1400 samples, which included 200 sera, 200 intestinal swabs, and 1000 organs and tissue samples, which included liver, spleen, bursa of Fabricius, heart, and breast muscles, were collected at the end of the study. Blood samples were collected and held at $37^{\circ} \mathrm{C}$ for $30 \mathrm{~min}$, then centrifuged at $4000 \mathrm{rpm}$ for $20 \mathrm{~min}$. Sera samples were stored at $-20^{\circ} \mathrm{C}$ for subsequent biochemical, immunological, and antioxidant 
assays (Soliman et al., 2017). The liver, spleen, bursa, and heart were kept in formalin for histopathological examination.

Thirty-two birds from each group were weighed at weekly intervals. The number of birds to be weighed $(n)$ was calculated using a simple random sampling design by Solvin's formula:

$$
n=N /\left(1+N e^{2}\right)
$$

given an acceptable error rate $(e)$ of $5 \%$ and a total population size of $N$.

Feed intake and water intake for each bird were calculated by dividing the total amount consumed in each group by the number of birds in this group. Bodyweight gain (BWG), FCR, and the performance index (PI) were calculated according to Soliman and Hassan (2017).

The behaviour of the broilers was evaluated for three hours a day at 9h00,14h00, and 21h00 during the first, third, and fifth weeks using Panasonic WV Ns202ae video camera (Panasonic India Pvt. Ltd., Haryana, India) suspended $1.5 \mathrm{~m}$ above the birds' heads (Li et al., 2015). The duration and frequency of the performed behaviours in each group were recorded every five minutes per hour using focal sampling method when the videotapes were replayed (Villagra et al., 2014).

Tonic immobility (TI) was induced by manual restraint. Each bird was laid on its back in a U-shaped cradle and held motionless by gently pressing its breast for $15 \mathrm{sec}$. The observer remained still, quiet, and out of sight until birds righted themselves again, and the duration of TI was recorded. If $\mathrm{TI}$ was not obtained after three attempts, an observation of 0 seconds was recorded. An observation of 600 seconds was recorded for a bird that remained immobile after $10 \mathrm{~min}$. The protocol was repeated at the first, third, and fifth weeks in ten individually identified broilers from each of the six groups (Sinkalu et al., 2016).

Total protein (TP) $(\mathrm{g} / \mathrm{dL})$, albumin (ALB) $(\mathrm{g} / \mathrm{dL})$, alanine aminotransferase $(\mathrm{ALT})(\mathrm{IU} / \mathrm{L})$, aspartate aminotransferase (AST) $(\mathrm{IU} / \mathrm{L})$, urea $(\mathrm{mg} / \mathrm{dL})$, and creatinine (Creat) $(\mathrm{mg} / \mathrm{dL})$, and the antioxidant markers total antioxidant capacity (TAC) ( $\mathrm{mM} / \mathrm{L})$, malondialdehyde (MDA) $(\mathrm{nmol} / \mathrm{mL})$, and superoxide dismutase (SOD) (U/mL) were measured in serum using Roche Integra 400 Plus chemical analyser (Roche Diagnostics Middle East, Dubai, United Arab Emirates). Serum immunoglobulins (IgG and $\mathrm{lgM}$ ) (mg/dL) were measured using Roche Elecsys 1010 immunoassay analyser (Roche Diagnostics Middle East, Dubai, United Arab Emirates) as described by Wu et al. (2017).

Intestinal swabs and breast muscle samples were prepared as recommended by APHA (2012). Tenfold serial dilutions up to $10^{-8}$ were prepared. Bacterial counts were performed using a drop plate technique as recommended by Kim and Lee (2016) and Soliman et al. (2016). Standard plate count and eosin methylene blue agars were used for the total bacterial count (TBC) and total Enterobacteriaceae count (TEC), respectively, at $37^{\circ} \mathrm{C}$ for 24 - 48 hours. Plates were counted with a dark-field colony counter (Murray et al., 2015).

All birds were slaughtered at the end of the experiment and tissue samples from the liver, heart, spleen, and bursa of Fabricius were harvested. The samples were fixed in $10 \%$ buffered formalin. The specimens were cut into 5-mm thickness, put into tissue cassettes, dehydrated manually by transferring through a series of alcohols with different concentrations, cleared in two changes of xylene, embedded in paraffin wax, cut into $4 \mu \mathrm{m}$ thick sections, and stained with haematoxylin and eosin (Bancroff, 1990). The histological sections of the examined organs were visualized using a light microscope under $(x 10)$ and $(x 20)$ magnification and photographed using an Olympus DP-73 microscope digital camera (Olympus MEA FZLLC, Dubai, United Arab Emirates).

Statistical analysis was carried out using SAS-STAT version 9.4 for Windows (SAS Institute, Inc., Cary North Carolina, USA). Analysis of variance was used to detect treatment effects with a three-way factorial model:

$$
y_{i j k l}=\mu+\alpha_{i}+\beta_{j}+(\alpha \beta)_{i j}+t_{k}+(\alpha t)_{i k}+(\beta t)_{j k}+(\alpha \beta t)_{i j k}+e_{i j k l}
$$

where: $y_{i j k l}$ was a measurement from the $l$ th a bird of the $k$ th age, and $i$ th breed that was subjected to the $j$ th treatment, $\mu$ was overall mean;

$\alpha_{i}$ was the fixed effect of breed;

$\beta_{j}$ was the fixed effect of supplement treatment;

$(\alpha \beta)_{i j}$ was the interaction effect of broiler's breed by supplement treatment;

$(\alpha t)_{i k}$ was the interaction effect of broiler's breed by its age;

$(\beta t)_{j k}$ was the interaction effect of treatment with age;

$(\alpha \beta t)_{i j k}$ was the corresponding three-way interaction; and

$e_{i j k l}$ was random error. 
For those dependent variables that were measured only once, the main effect of age and interactions involving age were omitted from the analysis. Total bacterial count and TEC were log-transformed prior to analysis. Pearson's correlation was calculated to reveal the association between immunoglobulin $\mathrm{G}$ and $\mathrm{M}$ concentrations with TBC and TEC of intestinal swabs and breast muscles, and with antioxidant activity. The differences were considered highly significant at $(P<0.01)$, significant at $(P \leq 0.05)$, and non-significant at $(P$ $>0.05$ ).

\section{Results and Discussion}

On average, the Ross broilers that were supplemented with Se (G4 and G5) gained more weight than any of the other groups, which were similar (Table 1). Feed intake differed among all of the groups. However, those broilers in G5 and G6 consumed substantially more feed than any other groups and thus had higher FCRs. The Ross broilers in G5 and G6 had reduced performance indices relative to their counterpart Arbor broilers. However, when the broilers were supplemented with NS, Ross broilers had a greater performance index than Arbor broilers. Water intake followed a pattern that was similar to the performance index, with Ross broilers in G5 and G6 consuming more water than their counterpart Arbor broilers, and with the NS supplemented Ross broilers consuming less water than the Arbor broilers.

Table 1 Means $( \pm$ SE) for breed by treatment interaction effects on growth, feed and water intake, and calculate indices for broilers that were supplemented with selenium or nano-selenium under the influence of heat stress

\begin{tabular}{lccccc}
\hline Breed $x$ treatment & Weight gain, $g$ & Feed intake, $g$ & $\begin{array}{c}\text { Feed conversion } \\
\text { ratio }\end{array}$ & $\begin{array}{c}\text { Performance } \\
\text { index }\end{array}$ & Water intake, ml \\
\hline Arbor*NS & $387.4^{\mathrm{ab}} \pm 9.7$ & $580.9^{\mathrm{c}} \pm 0.0$ & $1.48^{\mathrm{b}} \pm 0.06$ & $6.3^{\mathrm{b}} \pm 0.19$ & $151.2^{\mathrm{c}} \pm 6.7$ \\
Arbor ${ }^{*}$ Se & $386.3^{\mathrm{ab}} \pm 9.1$ & $519.6^{\mathrm{f}} \pm 0.0$ & $1.43^{\mathrm{b}} \pm 0.05$ & $7.0^{\mathrm{a}} \pm 0.11$ & $174.2^{\mathrm{b}} \pm 6.1$ \\
Arbor ${ }^{*}$ control & $368.3^{\mathrm{b}} \pm 8.8$ & $557.0^{\mathrm{d}} \pm 0.0$ & $1.54^{\mathrm{b}} \pm 0.06$ & $6.1^{\mathrm{b}} \pm 0.18$ & $181.1^{\mathrm{b}} \pm 6.7$ \\
Ross $^{*} \mathrm{NS}$ & $412.8^{\mathrm{a}} \pm 9.1$ & $543.0^{\mathrm{e}} \pm 0.0$ & $1.40^{\mathrm{b}} \pm 0.06$ & $7.5^{\mathrm{a}} \pm 0.19$ & $138.5^{\mathrm{d}} \pm 6.5$ \\
Ross $^{*}$ Se & $407.5^{\mathrm{a}} \pm 8.1$ & $664.3^{\mathrm{a}} \pm 0.0$ & $1.74^{\mathrm{a}} \pm 0.05$ & $6.1^{\mathrm{b}} \pm 0.12$ & $212.8^{\mathrm{a}} \pm 6.7$ \\
Ross $^{*}$ control & $364.2^{\mathrm{b}} \pm 8.5$ & $643.2^{\mathrm{b}} \pm 0.0$ & $1.76^{\mathrm{a}} \pm 0.05$ & $5.1^{\mathrm{c}} \pm 0.11$ & $198.1^{\mathrm{a}} \pm 5.2$ \\
P-value & $<0.01$ & $<0.01$ & $<0.01$ & $<0.01$ & $<0.01$ \\
\hline
\end{tabular}

a,b,c,d Within each column, means that lack a common superscript are deemed different at $P \leq 0.05$

NS: nano-selenium supplement; Se: inorganic selenium supplement; control: unsupplemented

However, the three-way interaction of breed, supplement treatment, and age was highly significant for WG, FI, FCR, PI, and water intake. Thus, differences in the time trends observed for these measures of performance may be important for a comprehensive interpretation of the data. In general, the broilers all gained weight throughout the experiment (Table 2), with G3 being an aberration in week 4 . Because the birds grew over time, feed intake increased with the age of the birds. However, the feed intake of G1, G3, and G6 plateaued or decreased after week 4. For all groups, the performance index increased over time. While weekly fluctuations were noted for the groups at week 5 , all of the groups were similar. Water intake also increased as the birds grew over time. However, the magnitude of the increase between weeks 4 and 5 was far less for G4 than for any of the other groups. The overall means for WG and the performance index revealed the greater $(P<0.01)$ of Ross broilers $(395.2 \mathrm{~g}$ and 6.2, respectively) when compared with Arbor broilers (380.6 $\mathrm{g}$ and 6.1 , respectively). 
Table 2 Weekly means ( \pm SE) for the joint effects of breed and treatment growth, feed and water intake, and calculated indices for broilers that were supplemented with selenium or nano-selenium and under the influence of heat stress

\begin{tabular}{|c|c|c|c|c|c|c|}
\hline Breed $x$ treatment & Week & Weight gain, $g$ & Feed intake, $g$ & $\begin{array}{c}\text { Feed } \\
\text { conversion } \\
\text { ratio }\end{array}$ & $\begin{array}{c}\text { Performance } \\
\text { index }\end{array}$ & Water intake, $\mathrm{ml}$ \\
\hline \multirow[t]{5}{*}{ Arbor*NS } & 1 & $83.1^{d} \pm 5.8$ & $109.2^{d} \pm 0.0$ & $1.3^{c} \pm 0.10$ & $0.9^{e} \pm 0.01$ & $50.4^{\mathrm{e}} \pm 11.0$ \\
\hline & 2 & $262.5^{c} \pm 9.0$ & $331.2^{c} \pm 0.0$ & $1.2^{c} \pm 0.04$ & $3.0^{d} \pm 0.16$ & $95.4^{d} \pm 3.7$ \\
\hline & 3 & $476.1^{b} \pm 23.3$ & $687.0^{b} \pm 0.0$ & $1.4^{b} \pm 0.08$ & $6.0^{c} \pm 0.44$ & $153.3^{c} \pm 13.0$ \\
\hline & 4 & $494.9^{b} \pm 31.9$ & $888.6^{a} \pm 0.0$ & $1.8^{a} \pm 0.12$ & $7.6^{b} \pm 0.53$ & $191.8^{b} \pm 8.0$ \\
\hline & 5 & $620.4^{a} \pm 18.4$ & $888.6^{a} \pm 0.0$ & $1.4^{b} \pm 0.04$ & $13.8^{a} \pm 0.46$ & $265.3^{a} \pm 13.2$ \\
\hline \multirow[t]{5}{*}{ Arbor ${ }^{*}$ Se } & 1 & $83.8^{c} \pm 5.0$ & $108.7^{e} \pm 0.0$ & $1.3^{c} \pm 0.07$ & $0.9^{e} \pm 0.02$ & $47.1^{\mathrm{e}} \pm 9.7$ \\
\hline & 2 & $216.9^{b} \pm 23.1$ & $306.5^{d} \pm 0.0$ & $1.7^{a} \pm 0.36$ & $2.5^{d} \pm 0.36$ & $96.1^{d} \pm 7.0$ \\
\hline & 3 & $549.1^{\mathrm{a}} \pm 26.1$ & $663.0^{c} \pm 0.0$ & $1.2^{c} \pm 0.05$ & $7.3^{c} \pm 0.43$ & $166.2^{\mathrm{c}} \pm 15.8$ \\
\hline & 4 & $542.3^{a} \pm 16.4$ & $739.2^{b} \pm 0.0$ & $1.3^{c} \pm 0.04$ & $10.5^{\mathrm{b}} \pm 0.37$ & $237.6^{b} \pm 10.8$ \\
\hline & 5 & $539.6^{a} \pm 34.9$ & $780.3^{a} \pm 0.0$ & $1.5^{\mathrm{b}} \pm 0.11$ & $13.7^{a} \pm 1.10$ & $3240^{a} \pm 18.8$ \\
\hline \multirow[t]{5}{*}{ Arbor*control } & 1 & $91.3^{e} \pm 3.4$ & $121.5^{\mathrm{e}} \pm 0.0$ & $1.3^{b} \pm 0.04$ & $1.0^{d} \pm 0.06$ & $46.6^{e} \pm 9.1$ \\
\hline & 2 & $251.2^{d} \pm 10.5$ & $367.6^{d} \pm 0.0$ & $1.4^{b} \pm 0.05$ & $2.6^{c} \pm 0.17$ & $97.6^{d} \pm 4.1$ \\
\hline & 3 & $517.9^{b} \pm 22.1$ & $687.0^{c} \pm 0.0$ & $1.3^{b} \pm 0.05$ & $6.8^{b} \pm 0.43$ & $178.7^{c} \pm 17.8$ \\
\hline & 4 & $391.6^{c} \pm 26.7$ & $817.6^{a} \pm 0.0$ & $2.1^{a} \pm 0.14$ & $6.2^{b} \pm 0.46$ & $220.7^{b} \pm 12.5$ \\
\hline & 5 & $589.5^{a} \pm 23.2$ & $791.5^{b} \pm 0.0$ & $1.3^{b} \pm 0.05$ & $14.0^{a} \pm 0.66$ & $361.7^{a} \pm 38.9$ \\
\hline \multirow[t]{5}{*}{ Ross*NS } & 1 & $58.3^{d} \pm 4.8$ & $91.7^{e} \pm 0.0$ & $1.6^{a} \pm 0.15$ & $0.7^{e} \pm 0.08$ & $44.0^{\mathrm{e}} \pm 8.9$ \\
\hline & 2 & $225.4^{\mathrm{C}} \pm 15.3$ & $294.4^{d} \pm 0.0$ & $1.3^{b} \pm 0.10$ & $2.6^{d} \pm 0.26$ & $102.6^{d} \pm 4.0$ \\
\hline & 3 & $585.4^{b} \pm 12.6$ & $669.7^{c} \pm 0.0$ & $1.1^{c} \pm 0.02$ & $8.0^{c} \pm 0.24$ & $146.8^{c} \pm 18.6$ \\
\hline & 4 & $583.5^{b} \pm 16.8$ & $796.6^{b} \pm 0.0$ & $1.3^{b} \pm 0.03$ & $11.0^{\mathrm{b}} \pm 0.41$ & $186.8^{\mathrm{b}} \pm 11.8$ \\
\hline & 5 & $611.5^{a} \pm 23.8$ & $862.5^{a} \pm 0.0$ & $1.4^{b} \pm 0.05$ & $15.0^{a} \pm 0.71$ & $212.5^{\mathrm{a}} \pm 15.4$ \\
\hline \multirow[t]{5}{*}{ Ross ${ }^{\star} \mathrm{Se}$} & 1 & $73.9^{d} \pm 10.0$ & $127.4^{e} \pm 0.0$ & $2.2^{a} \pm 0.43$ & $0.8^{e} \pm 0.05$ & $52.1^{e} \pm 11.5$ \\
\hline & 2 & $324.0^{c} \pm 13.4$ & $400.2^{d} \pm 0.0$ & $1.2^{d} \pm 0.05$ & $3.6^{d} \pm 0.23$ & $113.2^{\mathrm{d}} \pm 7.9$ \\
\hline & 3 & $495.9^{b} \pm 21.9$ & $813.6^{c} \pm 0.0$ & $1.6^{c} \pm 0.08$ & $5.7^{c} \pm 0.31$ & $194.9^{c} \pm 23.6$ \\
\hline & 4 & $478.9^{b} \pm 12.0$ & $958.3^{\mathrm{b}} \pm 0.0$ & $2.0^{\mathrm{b}} \pm 0.05$ & $7.0^{b} \pm 0.22$ & $291.2^{\mathrm{b}} \pm 16.4$ \\
\hline & 5 & $664.9^{a} \pm 33.3$ & $1022.2^{a} \pm 0.0$ & $1.5^{\mathrm{c}} \pm 0.08$ & $13.6^{a} \pm 0.83$ & $412.6^{a} \pm 20.5$ \\
\hline \multirow[t]{5}{*}{ Ross ${ }^{*}$ control } & 1 & $88.6^{d} \pm 5.9$ & $137.2^{\mathrm{e}} \pm 0.0$ & $1.6^{b} \pm 0.10$ & $0.8^{e} \pm 0.09$ & $52.6^{e} \pm 9.7$ \\
\hline & 2 & $261.9^{c} \pm 11.4$ & $367.3^{d} \pm 0.0$ & $1.4^{c} \pm 0.05$ & $2.8^{d} \pm 0.17$ & $114.7^{d} \pm 8.9$ \\
\hline & 3 & $471.8^{b} \pm 32.4$ & $789.8^{c} \pm 0.0$ & $1.7^{b} \pm 0.16$ & $5.2^{c} \pm 0.50$ & $202.8^{c} \pm 18.1$ \\
\hline & 4 & $476.0^{b} \pm 25.9$ & $985.3^{a} \pm 0.0$ & $2.0^{a} \pm 0.12$ & $6.6^{b} \pm 0.39$ & $257.1^{b} \pm 10.7$ \\
\hline & 5 & $523.0^{a} \pm 29.2$ & $963.4^{b} \pm 0.0$ & $1.9^{a} \pm 0.14$ & $10.1^{a} \pm 0.62$ & $363.4^{a} \pm 19.3$ \\
\hline P-value & & $<0.01$ & $<0.01$ & $<0.01$ & $<0.01$ & $<0.01$ \\
\hline
\end{tabular}

a,b,c,d,e Within each column, means lacking a common superscript are deemed different at $P \leq 0.05$

NS: nano-selenium supplement; Se: inorganic selenium supplement; control: unsupplemented

Total protein was reduced $(P<0.01)$ in broilers of both breeds when they received NS (G1 and G4) relative to those birds that were supplemented with $\mathrm{Se}$ or in the unsupplemented control groups (Table 3). Within breed, the group that was supplemented with Se was not detectibly different from the unsupplemented control. In the Ross broilers, a similar pattern was observed for AST. However, in the Arbor broilers, the pattern of responses in AST was reversed with the NS-supplemented broilers exhibiting a higher level than G2 and G3, which were again similar. The level of ALB was also reduced $(P<0.01)$ in broilers that were supplemented with NS compared with those that were either supplemented with Se or were not supplemented. However, the level of ALB in birds that were supplemented with Se was lower $(P<0.05)$ than those that were unsupplemented. There was a highly significant reduction $(P<0.01)$ of ALT by broilers in $\mathrm{G} 4$ 
compared with G5 and G6, with no significant difference between G5 and G6. In the Arbor broilers, there was a highly significant reduction $(P<0.01)$ in $\mathrm{G} 1$ and $\mathrm{G} 2$ compared with $\mathrm{G} 3$, with the contrast of $\mathrm{G} 1$ and $\mathrm{G} 2$ being non-significant. Urea was reduced $(P<0.01)$ in $\mathrm{G} 4$ compared with $\mathrm{G} 5$ and $\mathrm{G} 6$, and in $\mathrm{G} 1$ compared with G2, but not compared with G3. The two breeds had similar treatment means for creatinine, with supplemental selenium elevating the levels $(P<0.01)$, but less so in $\mathrm{G} 1$ and $\mathrm{G} 4$ than in $\mathrm{G} 2$ and $\mathrm{G} 5$.

Table 3 Biochemical profiles (mean \pm SE) of Arbor and Ross broilers supplemented with selenium and nanoselenium under the influence of heat stress

\begin{tabular}{lcccccc}
\hline Breed*treatment & $T P, g \cdot d L^{-1}$ & $A L B, g \cdot d L^{-1}$ & $A L T, I U . L^{-1}$ & $A S T, I U . L^{-1}$ & Urea, $m g . d L^{-1}$ & $C R T, m g . d L^{-1}$ \\
\hline Arbor $N S$ & $10.1^{\mathrm{b}} \pm 0.40$ & $1.0^{\mathrm{f}} \pm 0.08$ & $1.2^{\mathrm{b}} \pm 0.18$ & $43.6^{\mathrm{a}} \pm 1.7$ & $43.7^{\mathrm{b}} \pm 0.84$ & $2.2^{\mathrm{b}} \pm 0.14$ \\
Arbor & $10.3^{\mathrm{b}} \pm 0.42$ & $1.3^{\mathrm{e}} \pm 0.09$ & $2.3^{\mathrm{b}} \pm 0.19$ & $39.7^{\mathrm{b}} \pm 1.8$ & $48.3^{\mathrm{a}} \pm 0.88$ & $3.5^{\mathrm{a}} \pm 0.15$ \\
Arbor & $11.8^{\mathrm{a}} \pm 0.45$ & $3.3^{\mathrm{a}} \pm 0.10$ & $4.6^{\mathrm{a}} \pm 0.20$ & $38.4^{\mathrm{b}} \pm 2.0$ & $42.2^{\mathrm{b}} \pm 0.95$ & $0.9^{\mathrm{c}} \pm 0.16$ \\
Ross ${ }^{*} \mathrm{NS}$ & $10.6^{\mathrm{b}} \pm 0.44$ & $1.5^{\mathrm{d}} \pm 0.09$ & $2.6^{\mathrm{b}} \pm 0.19$ & $31.6^{\mathrm{c}} \pm 1.9$ & $28.5^{\mathrm{d}} \pm 0.89$ & $2.3^{\mathrm{b}} \pm 0.16$ \\
Ross & $11.8^{\mathrm{a}} \pm 0.42$ & $2.2^{\mathrm{c}} \pm 0.09$ & $3.7^{\mathrm{a}} \pm 0.20$ & $47.1^{\mathrm{a}} \pm 2.0$ & $48.3^{\mathrm{a}} \pm 0.93$ & $3.7^{\mathrm{a}} \pm 0.15$ \\
Ross & $11.5^{\mathrm{a}} \pm 0.44$ & $2.9^{\mathrm{b}} \pm 0.09$ & $3.8^{\mathrm{a}} \pm 0.20$ & $44.3^{\mathrm{a}} \pm 2.0$ & $37.3^{\mathrm{a}} \pm 0.93$ & $0.6^{\mathrm{c}} \pm 0.16$ \\
$P$-value & 0.010 & 0.000 & 0.000 & 0.000 & 0.000 & 0.000 \\
& & & & & & \\
\hline
\end{tabular}

a,b,c,d Within each column, means that lack a common superscript are deemed different at $\mathrm{P} \leq 0.05$

NS: nano-selenium supplement; Se: inorganic selenium supplement; control: unsupplemented

TP: total protein, ALB: albumin, ALT: alanine aminotransferase, AST: aspartate aminotransferase, CRT: creatinine

A synchronized and highly significant increase $(P<0.01)$ of immunoglobulin $\mathrm{G}$, immunoglobulin $\mathrm{M}$, total antioxidant capacity, malondialdehyde, and superoxide dismutase (Table 4) was observed in both breeds of broilers, with NS supplemented G1 and G4 having increased immunoglobulin concentrations and levels of antioxidant enzymes relative to the control groups (G3 and G6). Responses in immunoglobulin and antioxidant levels in G2 and G5 were intermediate between the NS supplemented groups (G1 and G4) and the control groups ( $G 3$ and $G 6$ ).

Table 4 Immunoglobulin concentrations and levels of antioxidant enzymes in broilers supplemented with selenium and nano-selenium under the influence of heat stress

\begin{tabular}{|c|c|c|c|c|c|}
\hline \multirow[b]{2}{*}{ Breed*treatment } & \multicolumn{2}{|c|}{ Immunoglobulin } & \multicolumn{3}{|c|}{ Antioxidant enzymes } \\
\hline & $\mathrm{lgG}, \mathrm{mg} / \mathrm{dL}$ & $\operatorname{lgM}, \mathrm{mg} / \mathrm{dL}$ & $\mathrm{TAC}, \mathrm{mM} / \mathrm{L}$ & $\mathrm{MDA}, \mathrm{nmol} / \mathrm{mL}$ & $\mathrm{SOD}, \mathrm{U} / \mathrm{mL}$ \\
\hline Arbor ${ }^{*} \mathrm{NS}$ & $1691.9^{c} \pm 7.64$ & $375.4^{c} \pm 1.97$ & $2.0^{a} \pm 0.012$ & $27.4^{b} \pm 0.22$ & $273.8^{a} \pm 1.36$ \\
\hline Arbor ${ }^{*} \mathrm{Se}$ & $1674.0^{\mathrm{d}} \pm 7.45$ & $367.7^{d} \pm 1.92$ & $1.3^{f} \pm 0.011$ & $14.5^{d} \pm 0.21$ & $255.3^{c} \pm 1.32$ \\
\hline Arbor ${ }^{*}$ control & $1343.9^{f} \pm 8.07$ & $270.4^{\dagger} \pm 2.08$ & $1.4^{\mathrm{e}} \pm 0.012$ & $7.4^{f} \pm 0.23$ & $251.4^{\mathrm{C}} \pm 1.43$ \\
\hline Ross*NS & $2003.4^{a} \pm 7.54$ & $505.9^{a} \pm 1.94$ & $1.9^{b} \pm 0.012$ & $30.3^{a} \pm 0.21$ & $275.1^{\mathrm{a}} \pm 1.34$ \\
\hline Ross*Se & $1926.6^{b} \pm 7.90$ & $482.8^{b} \pm 2.03$ & $1.6^{c} \pm 0.012$ & $17.5^{c} \pm 0.22$ & $261.4^{b} \pm 1.40$ \\
\hline Ross*control & $1382.5^{e} \pm 7.90$ & $305.5^{e} \pm 2.03$ & $1.5^{d} \pm 0.012$ & $8.2^{\mathrm{e}} \pm 0.23$ & $256.3^{c} \pm 1.40$ \\
\hline P-value & 0.000 & 0.000 & 0.000 & 0.000 & 0.000 \\
\hline
\end{tabular}

a,b,c,d,e,f Within each column, means that lack a common superscript are deemed different at $P \leq 0.05$

NS: nano-selenium supplement; Se: inorganic selenium supplement; control: unsupplemented

IgG: Immunoglobulin G, IgM: immunoglobulin M, TAC: total antioxidant capacity, MDA: malondialdehyde, SOD:

superoxide dismutase

The total bacterial count of intestinal swabs taken from selenium-supplemented broilers increased $(P$ $<0.01$ ) relative to $\mathrm{G} 3$ and $\mathrm{G} 6$ (Table 5). This increase also occurred for TEC from the intestinal swabs of $\mathrm{G} 1$ and $\mathrm{G} 2$ relative to $\mathrm{G} 3$ and for TBC from the breast muscles. However, G4, G5, and G6 were similar in TEC 
from the intestinal swabs and TBC from the breast muscles. The TEC levels from breast muscle were similar for $\mathrm{G} 1$ and $\mathrm{G} 3$, and for $\mathrm{G} 4$ and $\mathrm{G} 6$, but elevated in $\mathrm{G} 2$ and $\mathrm{G} 5$ relative to the corresponding control groups.

Table 5 Logarithm bacterial load (mean \pm SE) in the intestine and breast muscles of broiler breeds supplemented with selenium and nano-selenium under the influence of heat stress

\begin{tabular}{|c|c|c|c|c|}
\hline \multirow[b]{2}{*}{ Breed ${ }^{*}$ treatment } & \multicolumn{2}{|c|}{ Intestinal swabs } & \multicolumn{2}{|c|}{ Breast muscles } \\
\hline & $\begin{array}{c}\text { TBC } \\
\log \mathrm{CFU} / \mathrm{mL} \\
\end{array}$ & $\begin{array}{c}\text { TEC } \\
\log \mathrm{CFU} / \mathrm{mL} \\
\end{array}$ & $\begin{array}{c}\text { TBC } \\
\log \mathrm{CFU} / \mathrm{mL} \\
\end{array}$ & $\begin{array}{c}\text { TEC } \\
\log \mathrm{CFU} / \mathrm{mL} \\
\end{array}$ \\
\hline Arbor ${ }^{*} \mathrm{NS}$ & $4.6^{b} \pm 0.06$ & $3.2^{\mathrm{a}} \pm 0.11$ & $3.8^{a} \pm 0.02$ & $1.5^{\mathrm{b}} \pm 0.07$ \\
\hline Arbor ${ }^{*}$ Se & $5.5^{a} \pm 0.05$ & $3.5^{\mathrm{a}} \pm 0.10$ & $4.1^{a} \pm 0.03$ & $2.4^{\mathrm{a}} \pm 0.06$ \\
\hline Arbor*control & $3.4^{e} \pm 0.06$ & $2.2^{b} \pm 0.11$ & $3.0^{c} \pm 0.02$ & $0.9^{b} \pm 0.07$ \\
\hline Ross*NS & $4.2^{d} \pm 0.05$ & $1.9^{\mathrm{b}} \pm 0.10$ & $3.3^{b} \pm 0.02$ & $0.7^{b} \pm 0.07$ \\
\hline Ross ${ }^{*} \mathrm{Se}$ & $4.5^{c} \pm 0.06$ & $2.3^{b} \pm 0.11$ & $3.4^{\mathrm{b}} \pm 0.02$ & $1.2^{\mathrm{b}} \pm 0.07$ \\
\hline Ross ${ }^{*}$ control & $3.4^{\mathrm{e}} \pm 0.06$ & $2.0^{\mathrm{b}} \pm 0.11$ & $3.1^{b} \pm 0.03$ & $0.8^{b} \pm 0.07$ \\
\hline$P$ value & 0.000 & 0.000 & 0.000 & 0.000 \\
\hline
\end{tabular}

a,b,c,d,e Within each column, means lacking a common superscript are deemed different at $P \leq 0.05$

NS: nano-selenium supplement; Se: inorganic selenium supplement; control: unsupplemented TBC: total bacterial count, TEC: total enterobacteriaceae count, CFU: colony forming unit

Pearson correlation coefficients (Table 6$)$ revealed relatively strong $(P<0.01)$ and positive associations between immunoglobulin concentrations and antioxidant levels and among observed levels of the antioxidants. The correlations of the intestinal total bacterial count with the other counts of bacteria were also relatively strong $(P<0.01)$, as was the correction of Enterobacteriaceae counts from the intestinal swabs and in breast muscle. The other correlations were substantially weaker. However, the positive correlations of intestinal bacteria count with immunoglobulin levels, and the correlations of superoxide dismutase with the bacterial counts (except in breast muscle) appear to be noteworthy.

Table 6 Correlation coefficients between immunoglobulin levels, traits indicative of bacterial load and antioxidant levels in heat-stressed broilers supplemented with selenium and selenium nanoparticles

\begin{tabular}{|c|c|c|c|c|c|c|c|c|}
\hline Traits & $\lg G$ & $\mathrm{TBCl}$ & $T B C B$ & TECI & TECB & $T A C$ & $M D A$ & $S O D$ \\
\hline $\lg M$ & & $0.257^{\star *}$ & 0.102 & 0.074 & 0.077 & $0.569^{* *}$ & $0.804^{\star *}$ & $0.518^{\star *}$ \\
\hline TBCI & $0.182^{*}$ & 1 & $0.663^{\star *}$ & $0.502^{* *}$ & $0.686^{* *}$ & 0.082 & $0.237^{*}$ & $0.344^{* *}$ \\
\hline TBCB & 0.002 & $0.663^{\star *}$ & 1 & -0.162 & 0.118 & 0.018 & 0.128 & -0.01 \\
\hline TECI & 0.053 & $0.502^{\star}$ & -0.102 & 1 & $0.881^{* *}$ & 0.093 & 0.135 & $0.374^{\star \star}$ \\
\hline TECB & 0.032 & $0.686^{* *}$ & 0.118 & $0.881^{* *}$ & 1 & -0.092 & 0.030 & $0.293^{* *}$ \\
\hline TAC & $0.551^{\star *}$ & 0.082 & 0.018 & 0.093 & -0.092 & 1 & $0.887^{\star *}$ & $0.674^{\star *}$ \\
\hline MDA & $0.763^{* *}$ & $0.237^{\star}$ & 0.128 & 0.135 & 0.030 & $0.887^{* *}$ & 1 & $0.672^{* *}$ \\
\hline SOD & $0.512^{\star *}$ & $0.344^{\star *}$ & -0.017 & $0.374^{\star *}$ & $0.293^{* *}$ & $0.674^{\star *}$ & $0.672^{* *}$ & 1 \\
\hline
\end{tabular}

${ }^{* *} P<0.01 ;{ }^{*} P<0.05$

$\lg G$ above diagonal and $\lg M$ below diagonal

IgG: immunoglobulin G, IgM: immunoglobulin M, TBCl: total bacterial count of intestinal swabs, TBCB: total bacterial count in breast muscle, TECI: total Enterobacteriaceae count of intestinal swabs, TECB: total Enterobacteriaceae count in breast muscle, TAC: total antioxidant capacity, MDA: malondialdehyde, SOD: superoxide dismutase

Broilers that were supplemented with NS or Se spent more time feeding, drinking and walking than the corresponding control birds (Table 7). Conversely, the unsupplemented broilers spent more time standing and resting. The duration of tonic immobility was less for the supplemented Arbor broilers and for the NS 
supplemented Ross broilers than the corresponding controls. It appears that the Arbor broilers were generally more frequently active than the Ross broilers and that the Ross broilers that were supplemented with NS (G4) were more frequently active than G5 and G6 broilers.

Figures 1,2, 3, and 4 contain representative photomicrographs of liver heart, spleen, and bursa of Fabricius, respectively. Within each figure, panels a, b, c, d, e, and fillustrate tissues from G1, G2, G3, G4, G5, and G6, respectively.

The Arbor broilers supplied with $0.5 \mathrm{ml} N \mathrm{NS}$ (G1) exhibited (Figure 1a) moderate perihepatitis and severe fibrosis around central vein with their hepatic cells expressing severe vacuolar degeneration, mild haemorrhage, and leukocytic infiltration compared with G3 broilers (Figure 1c). Heart tissue of the G1 broilers (Figure 2a) showed moderate pericarditis, severe myocardial degeneration, cytoplasmic vaculation, leukocytic infiltration, and mild congestion of the cardiac muscles in comparison with the G3 broilers (Figure 2c). Likewise, spleens of the G1 broilers exhibited moderate lymphoid depletion (Figure 3a) compared with the normal architecture of the G3 broilers (Figure 3c). Finally, the bursa of Fabricius had moderate lymphoid depletion of follicles with hyperplasia of follicular epithelium and interfollicular fibrosis (Figure 4a) compared with its normal appearance in the G3 control broilers (Figure 4c).

Supplementation of $0.5 \mathrm{ml}$ Se led to expression severe congestion of central vein with severe fibrosis, degeneration of hepatic cells, and leukocytic infiltration of the liver in G2 broilers (Figure $1 \mathrm{~b}$ ) compared with normal architecture of the liver in G3 control broilers (Figure 1c). The heart of broilers in G2 showed severe fibrinous pericarditis, which extended to include the myocardial muscle, with the myocardium showing cytoplasmic vaculation, mononuclear cell infiltration, congestion, and mild haemorrhage of the cardiac muscle (Figure $2 b$ ) compared with the image from the corresponding control in Figure 2c. The spleen from a Se supplemented broiler exhibited severe lymphoid depletion in Figure $3 b$ as compared with the normal architecture of an unsupplemented broiler in Figure 3c. In response to Se supplementation, the bursa of Fabricius (Figure 4b) exhibited moderate to severe lymphoid depletion of follicles with hyperplasia of the follicular epithelium and increased interfollicular fibrosis when compared with the appearance of normal tissue from an unsupplemented broiler (Figure 4c).

In Figure 1d, Ross broilers (G4) that were administered $0.5 \mathrm{ml}$ NS expressed focal leukocytic infiltration, and hepatocytes showed mild vacuolar degeneration compared with normal view in Figure $1 f$. Myocardium showed focal leukocytic infiltration, mild congestion, and cytoplasmic vaculation (Figure 2d) compared with the normal architecture (Figure 2f). The spleen in Figure 3d showed mild lymphoid depletion with mild haemorrhage and no lesions were detected in G6 Ross control broilers (Figure 3f). Bursa of Fabricius samples from the broilers in G4 reflected normal follicular epithelium, and normal lymphoid follicles with mild interfollicular fibrosis (Figure 4d) in reference to the normal picture in Figure $4 \mathrm{f}$.

The Ross broilers responded to Se supplementation by exhibiting mild perihepatitis in the liver, with the hepatic cells showing vaculation of cytoplasm, mild haemorrhage, and leukocytic infiltration (Figure 1e). Their heart tissue showed mild pericarditis, mild vacuolar degeneration of myocardium, mild haemorrhage, and leukocytic infiltration (Figure 2e). The spleen exhibited congestion of the splenic sinus with moderate lymphoid depletion (Figure 3e). Finally, the bursa of Fabricius of a Se-supplemented Ross broilers showed normal follicular epithelium with moderate lymphoid depletion and mild interfollicular fibrosis (Figure 4e). The histological appearance of the liver, heart, spleen, and bursa of Fabricius of broilers in G5 (Figures 1e, 2e, $3 e, 4 e)$ compared with the nearly typical histological architecture of the corresponding $\mathrm{G} 6$ control broilers (Figures 1f, 2f, 3f, and 4f). 
Table 7 Duration and frequency of behaviours and tonic immobility of Arbor and Cobb broilers supplemented with selenium and nano-selenium under the influence of heat stress

\begin{tabular}{|c|c|c|c|c|c|c|c|c|c|c|}
\hline & \multicolumn{9}{|c|}{ Behaviours } & \multirow{2}{*}{$\begin{array}{c}\text { Tonic } \\
\text { immobility }\end{array}$} \\
\hline & Feeding & Drinking & Walking & Standing & Resting & Preening & Stretching & Pecking & Flapping & \\
\hline \multicolumn{11}{|l|}{ Duration } \\
\hline Arbor*NS & $239.1^{a} \pm 46.9$ & $67.5^{c} \pm 19.5$ & $58.9^{a} \pm 9.1$ & $8.3^{e} \pm 2.7$ & $508.2^{d} \pm 57$ & & & & & $27.0^{\mathrm{e}} \pm 2.9$ \\
\hline Arbor ${ }^{*} \mathrm{Se}$ & $223.3^{b} \pm 56.5$ & $61.3^{d} \pm 9.9$ & $50.0^{b} \pm 8.1$ & $15.1^{c} \pm 5.4$ & $553.3^{b} \pm 63$ & & & & & $31.0^{d} \pm 3.4$ \\
\hline Arbor*C. & $163.3^{d} \pm 46.9$ & $38.3^{e} \pm 16.4$ & $40.8^{d} \pm 9.2$ & $33.3^{a} \pm 13.1$ & $593.3^{a} \pm 56$ & & & & & $51.0^{c} \pm 4.8$ \\
\hline Ross*NS & $224.3^{b} \pm 42.7$ & $127.5^{a} \pm 24.4$ & $50.0^{b} \pm 9.9$ & $11.5^{d} \pm 3.5$ & $551.6^{b} \pm 33$ & & & & & $79.0^{b} \pm 12.7$ \\
\hline Ross*Se & $217.5^{c} \pm 43.3$ & $105.8^{b} \pm 21.8$ & $44.1^{c} \pm 4.5$ & $13.5^{c} \pm 6.6$ & $540.8^{c} \pm 55$ & & & & & $106.0^{a} \pm 19.0$ \\
\hline Ross ${ }^{\star} \mathrm{C}$. & $173.1^{d} \pm 46.9$ & $61.6^{d} \pm 14.7$ & $23.3^{e} \pm 11.3$ & $27.5^{b} \pm 8.4$ & $552.5^{b} \pm 55$ & & & & & $107.0^{a} \pm 25.0$ \\
\hline $\mathrm{P}$-value & 0.00 & 0.002 & 0.001 & 0.00 & 0.04 & & & & & 0.00 \\
\hline \multicolumn{11}{|l|}{ Frequency } \\
\hline Arbor*NS & $2.25^{\mathrm{a}} \pm 0.4$ & $2.00^{\mathrm{a}} \pm 0.4$ & $6.08^{a} \pm 0.7$ & $0.75^{c} \pm 0.2$ & $3.83^{a} \pm 0.4$ & $1.67^{a} \pm 0.5$ & $1.42^{\mathrm{a}} \pm 0.3$ & $2.92 \pm 1.7$ & $0.75^{a} \pm 0.3$ & $0.3^{e} \pm 0.1$ \\
\hline Arbor ${ }^{*} \mathrm{Se}$ & $2.00^{c} \pm 0.3$ & $1.17^{e} \pm 0.2$ & $2.83^{b} \pm 0.4$ & $1.00^{b} \pm 0.3$ & $3.00^{\mathrm{a}} \pm 0.2$ & $1.33^{c} \pm 0.6$ & $0.92^{b} \pm 0.3$ & $0.17 \pm 0.2$ & $0.50^{b} \pm 0.2$ & $0.7^{c} \pm 0.2$ \\
\hline Arbor*C. & $1.42^{\mathrm{e}} \pm 0.3$ & $1.42^{c} \pm 0.2$ & $2.50^{b} \pm 0.4$ & $1.75^{a} \pm 0.6$ & $3.25^{a} \pm 0.3$ & $1.50^{b} \pm 0.9$ & $1.08^{b} \pm 0.3$ & $1.50 \pm 0.9$ & $0.17^{d} \pm 0.1$ & $1.0^{\mathrm{b}} \pm 0.1$ \\
\hline Ross*NS & $2.08^{b} \pm 0.3$ & $1.67^{b} \pm 0.2$ & $2.25^{b} \pm 0.3$ & $0.58^{d} \pm 0.2$ & $3.42^{a} \pm 0.2$ & $0.92^{d} \pm 0.4$ & $0.58^{c} \pm 0.2$ & $0.00 \pm 0.0$ & $0.35^{c} \pm 0.3$ & $0.5^{d} \pm 0.1$ \\
\hline Ross*Se & $2.00^{c} \pm 0.2$ & $1.33^{d} \pm 0.2$ & $1.50^{c} \pm 0.2$ & $0.50^{d} \pm 0.2$ & $2.92^{\mathrm{a}} \pm 0.3$ & $0.00^{e} \pm 0.0$ & $0.08^{e} \pm 0.1$ & $0.25 \pm 0.2$ & $0.17^{d} \pm 0.1$ & $1.0^{\mathrm{b}} \pm 0.3$ \\
\hline Ross ${ }^{\star} \mathrm{C}$. & $1.83^{d} \pm 0.4$ & $1.08^{e} \pm 0.2$ & $1.83^{c} \pm 0.3$ & $1.00^{b} \pm 0.3$ & $2.92^{a} \pm 0.3$ & $0.00^{e} \pm 0.0$ & $0.33^{d} \pm 0.1$ & $0.75 \pm 0.5$ & $0.17^{d} \pm 0.2$ & $1.3^{a} \pm 0.4$ \\
\hline P-value & 0.00 & 0.04 & 0.00 & 0.03 & 0.23 & 0.001 & 0.00 & 0.09 & 0.002 & 0.00 \\
\hline
\end{tabular}

a,b,c,d,e,f Within each column, means lacking a common superscript are deemed different at $P \leq 0.05$

NS: nano-selenium supplement; Se: inorganic selenium supplement; control: unsupplemented 

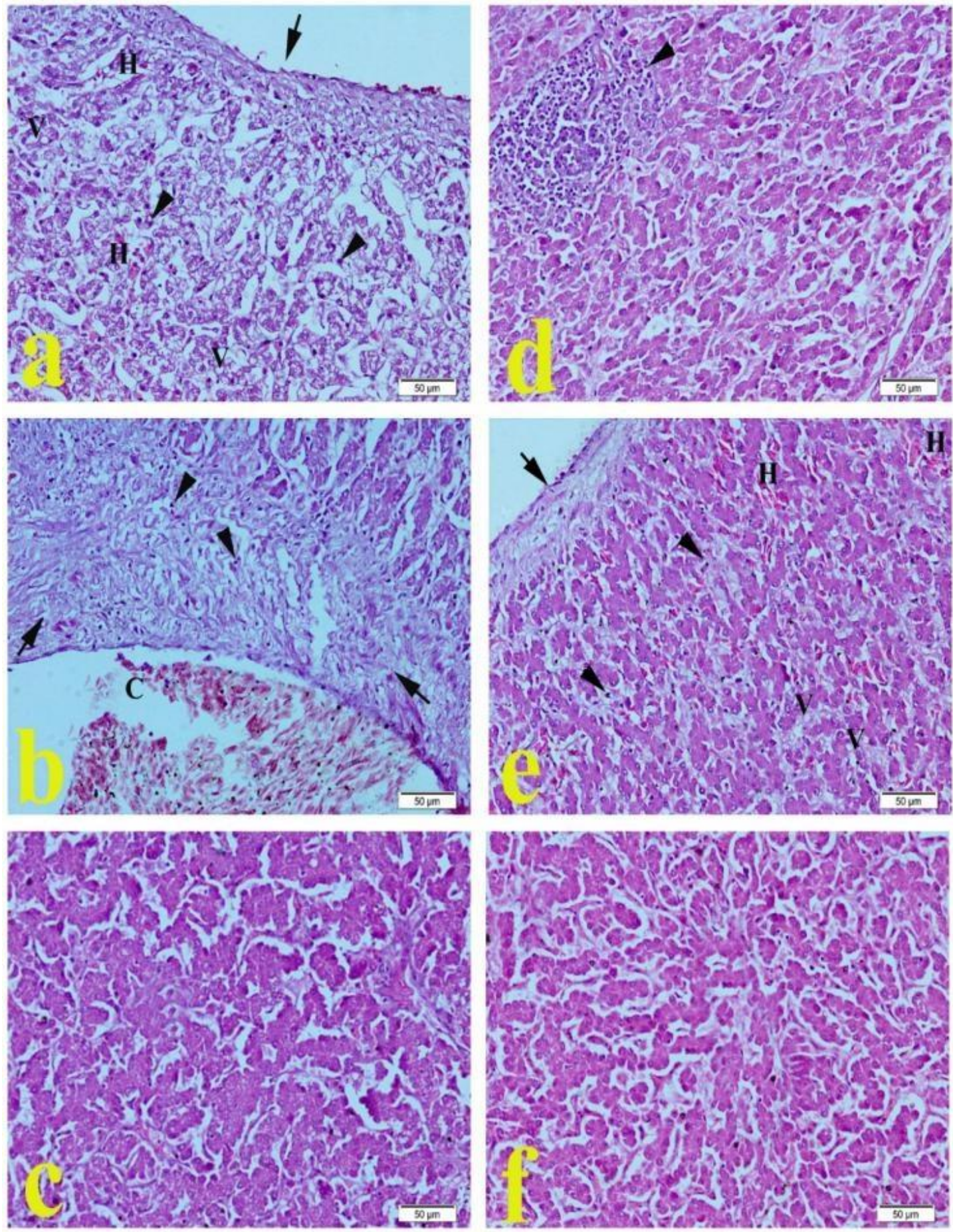

Figure 1 Histopathological sections of the liver stained with haematoxylin-eosin (20x): a) Arbor broilers supplemented with nano-selenium showing severe fibrosis around central vein (arrow), mononuclear cell infiltration (arrowhead), vaculation of hepatocytes cytoplasm $(\mathrm{V})$ and haemorrhage $(\mathrm{H})$; b) Arbor broilers supplemented with selenium showing fibrosis (arrow), mononuclear cell infiltration (arrowhead) and congestion of central vein (C); c) unsupplemented control Arbor broilers; d) liver of Ross broilers supplemented with nano-selenium; e) liver of Ross broilers supplemented with selenium; and (f) unsupplemented control Ross broilers bar $50 \mu \mathrm{m}$ 

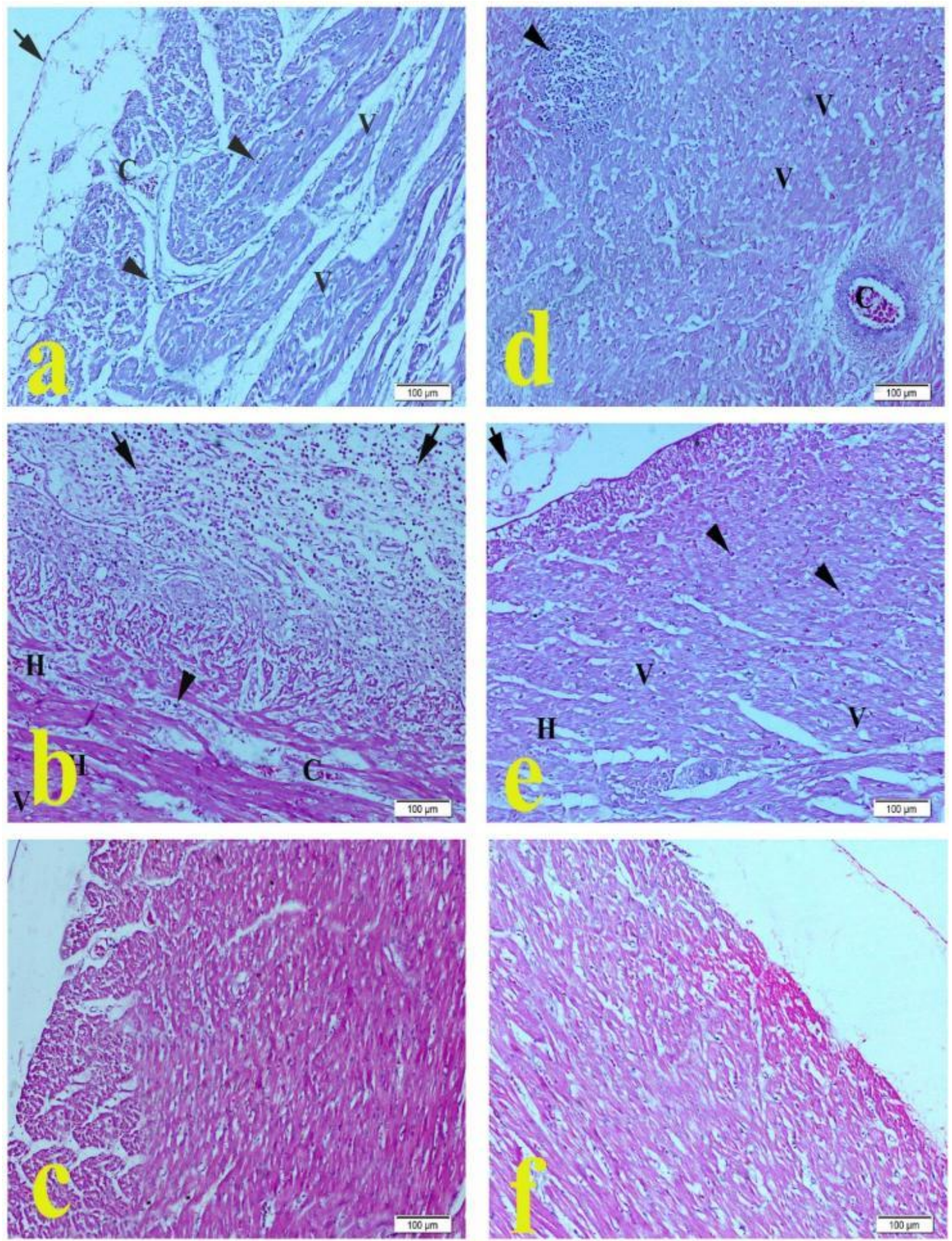

Figure 2 Histopathological section of heart stained with haematoxylin-eosin (10x): a) Arbor broilers supplemented with nano-selenium; b) Arbor broilers supplemented with selenium; c) unsupplemented control Arbor broilers; d) Ross broilers supplemented with nano-selenium; (e) Ross broilers supplemented with selenium; and f) unsupplemented control Ross broilers

Arrow: fibrinous pericarditis; arrowhead: mononuclear cell infiltration; V: vaculation of cytoplasm; C: congestion; bar = $100 \mu \mathrm{m}$ 

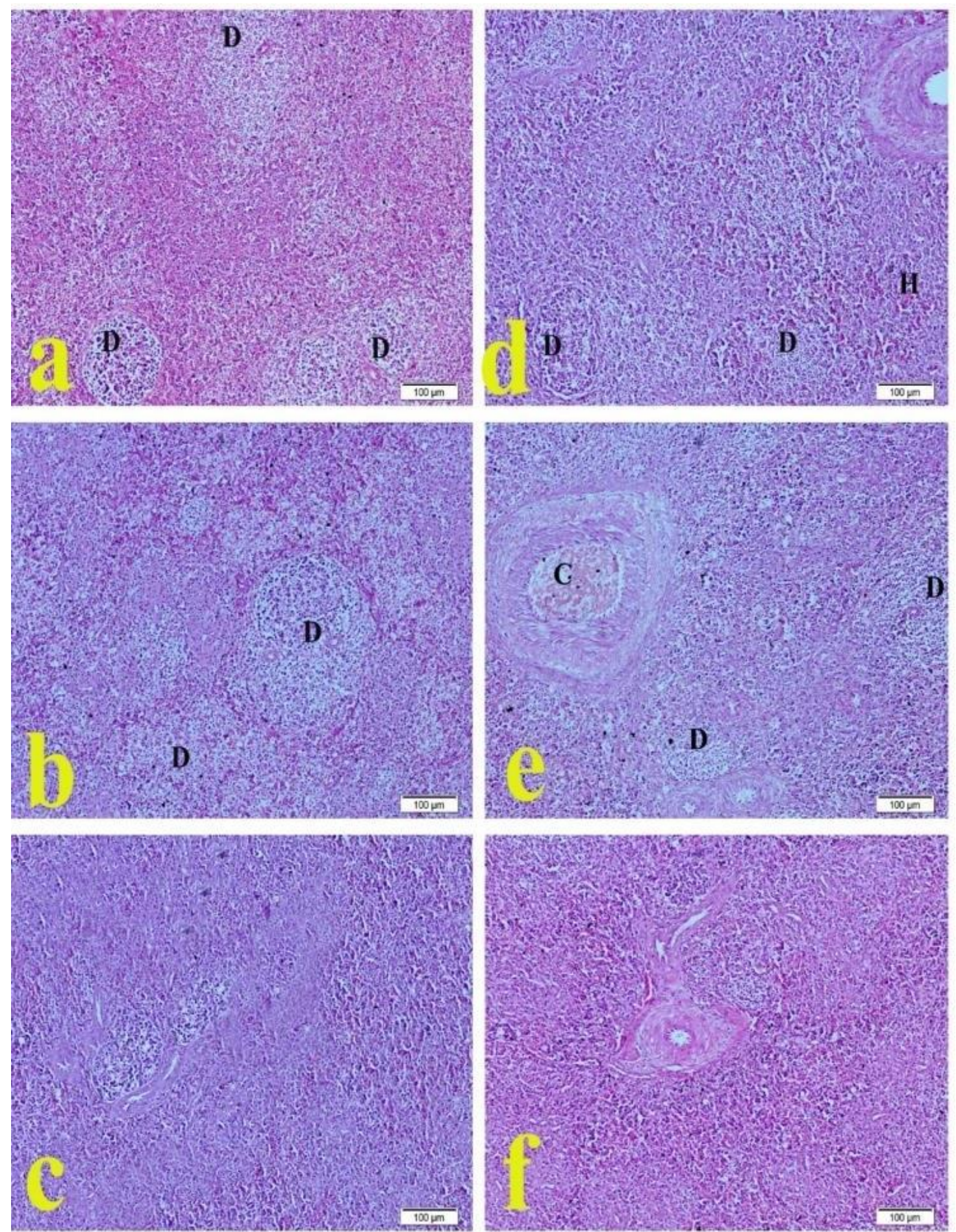

Figure 3 Histopathological section of the spleen stained with haematoxylin-eosin (10x): a) Arbor broilers supplemented with nano-selenium; b) Arbor broilers supplemented with selenium; c) unsupplemented control Arbor broilers; d) Ross broilers supplemented with nano-selenium; (e) Ross broilers supplemented with selenium; and f) unsupplemented control Ross broilers

D: depletion of lymphocytes; bar $=100 \mu \mathrm{m}$ 

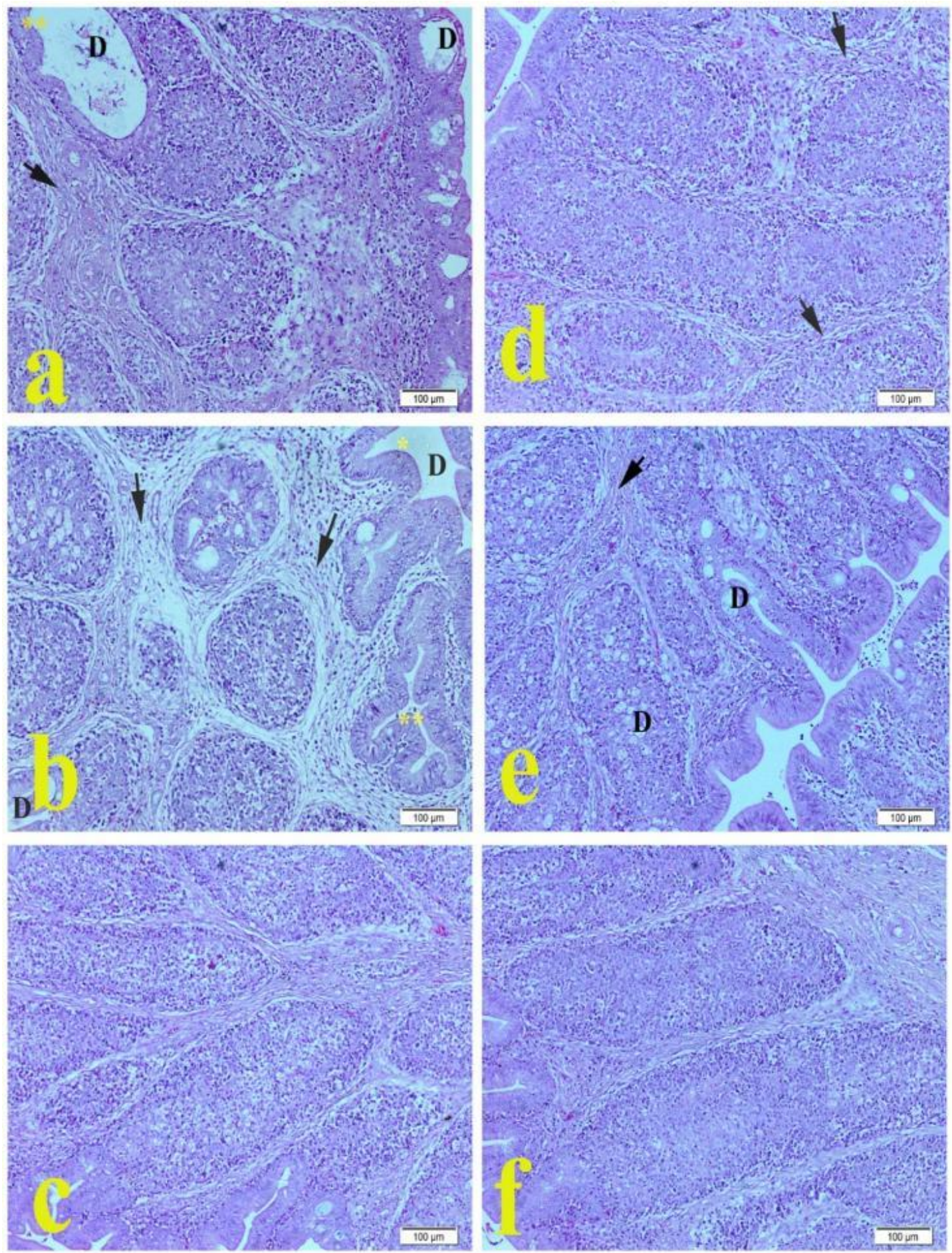

Figure 4 Histopathological section of the bursa stained with haematoxylin-eosin (10x): a) Arbor broilers supplemented with nano-selenium; b) Arbor broilers supplemented with selenium; c) unsupplemented control Arbor broilers; d) Arbor broilers supplemented with nano-selenium; e) Arbor broilers supplemented with selenium; and f) unsupplemented control Ross broilers

Bar $=100 \mu \mathrm{m}$; D: depletion of lymphocytes; ${ }^{* *}$ : hyperplasia of the follicular epithelium; arrow: increased interfollicular fibrosis

Selenium is an essential element in the nutrition of broilers. It plays an important role in many physiological functions, including calcium regulation, antioxidant redox balance and signalling, thyroid hormone metabolism, protein folding, lipid metabolism, and spermatozoa maturation (Lei, 2017). Selenium deficiency contributes to multiple disorders, especially in the presence of stress that originates from the surrounding micro-environment. These conditions are rarely observed because organic selenium is usually 
supplemented in rations composed of soya, oilseed, and grains. The selenite and selenate forms of selenium may also be provided in the vitamin and mineral mixes that are used by the poultry industry, especially post vaccination (Surai \& Fisinin, 2014). Lee et al. (2017) confirmed that elemental Se was the co-factor that was essential to activate 5'deiodinase enzyme. Later, the 5 'deiodinase acts as a key enzyme in the production of triiodothyronine (T3), which is important in controlling energy and protein absorption and thus could regulate animal growth.

In the present study, the productive performance of Arbor and Ross broilers that were exposed to heat stress was improved significantly by supplementation with NS and to a lesser degree with Se in their drinking water. These findings agree with those of Limaye et al. (2018), who demonstrated that dietary augmentation of Se with 0.10 to $0.25 \mathrm{mg} / \mathrm{kg}$ increased live bodyweight and decreased FCR, compared with diets without supplemental Se and vitamin E. Shabani et al. (2018) found that a supplement combination of $200 \mu \mathrm{g}$ Se and $8 \times 10^{9} \mathrm{CFU}$ probiotic per day reduced serum triglyceride concentrations and enhanced weight gain in birds. The current results were inconsistent with those of Zhao et al. (2018), who supplemented yellow broilers with 0.15 and $0.30 \mathrm{mg} \mathrm{Se} . \mathrm{kg}^{-1}$ and did not observe significant improvement in weight gain, but recorded a significant elevation of the glutathione (GSH) activity in the serum. Canoğullari et al. (2010) found no significant differences in final bodyweight, feed intake, feed efficiency, egg yield, and egg weight in Japanese quail supplemented with selenium at 0.2 and $0.1 \mathrm{mg} / \mathrm{kg}$ of ration.

In this study, supplemental NS alleviated the adverse influence of induced heat stress and minimized water intake. Attia et al. (2017), Saleh et al. (2018), and Kumbhar et al. (2018) also found that supplementation of broilers with antioxidants such as probiotics, trace elements, and vitamins was beneficial in alleviating the adverse effects imposed by a heat stress challenge. However, Mohanty et al. (2018) found no effect of the form or level of selenium on weight gain, feed intake or FCR. In addition, Ghalkhanbaz et al. (2018) observed that supplemental inorganic selenium at 1 - $8 \mathrm{ppm}$ did not affect the live bodyweight of broilers. They attributed this lack of effect to there being adequate selenium in the feedstuffs provided.

Serum concentrations of total protein, albumin, alanine aminotransferase, aspartate aminotransferase, urea, and creatinine in Ross and Arbor broilers were improved by supplementation with NS in this study. Ahmadi et al. (2018) reported a significant decrease in serum albumin with no effects on serum glucose and total protein in broilers supplemented with $0.1,0.2,0.3,0.4$, and $0.5 \mathrm{mg} \mathrm{NS} / \mathrm{kg}$ of ration. Yang et al. (2012) and Mohapatra et al. (2014) also recorded increased serum levels of glucose, total protein, aspartate aminotransferase, alkaline phosphatase, and globulins in birds supplemented with NS.

The present results revealed a positive influence of supplemental NS on serum concentrations of immunoglobulin $G$ and immunoglobulin $M$ in Ross and Arbor broilers. The enhanced levels of immunoglobulins were explained by Xiao et al. (2016) and Gulyas et al. (2016) as resulting from nanoselenium increasing protein synthesis and folding because there was a greater level of the eukaryotic translation initiation factor $5 \mathrm{~A}-1$. This factor is an important member of the protein synthesis pathway, hence the increased immunoglobulin $G$ and immunoglobulin $M$ serum concentrations. In the current study, immunoglobulins $G$ and $M$ also had weak positive correlations with the total bacterial count of intestinal swabs. The current results were similar to those of Chand et al. (2014) and Abudabos et al. (2017), who reported significant improvements in immunity with nano-zinc and NS supplementation. Total antioxidant activity and malondialdehyde and superoxide dismutase levels were markedly and equally improved in both Ross and Arbor broilers supplemented with NS compared with Se supplemented and unsupplemented broilers. The significant increase of antioxidant enzymes as reported by Safdari-Rostamabad et al. (2017) and Liao et al. (2012) was triggered by increased GSH mRNA expression in the liver and alleviated the negative influence of induced heat stress. The results also revealed strong positive correlations between immunoglobulin $\mathrm{G}$ and $\mathrm{M}$ serum concentrations with antioxidant activity. These results coincide with Gulyas et al. (2016), who reported improved GSH activities in liver and serum when feeding NS; they also stated that NS sized 100-500 nm contributed lower toxicity and higher bioavailability, but larger particle sizes of NS can contribute to dietary stress. Cai et al. (2012) and El-Deep et al. (2016) found increased mRNA GSH peroxidase (GSH-Px) in the liver and reduced malondialdehyde content of the liver and breast muscle when feeding NS to alleviate the impact of high ambient temperature. Markovic et al. (2018) recorded improvements in antioxidant activity, performance indices, carcass quality, and the chemical structure of meat from Cobb- 500 broilers supplemented with selenium-yeast.

The present study has shown a strong antimicrobial action from augmenting the drinking water with NS when broilers were exposed daily to mild heat stress. Our results agreed with those of Stanley et al. (2015), who revealed a significant inhibiting activity of NS on pathogenic microorganisms including Escherichia coli and Staphylococcus. In a seeming conflict with the aforementioned results, Stanley et al. (2015) also reported that NS supplementation increased beneficial bacteria in the gut of broilers, including Lactobacillus and Faecalibacterium. The present results were compatible with those of Yip et al. (2014), who revealed the antifungal properties of NS against Trichophyton rubrum. Kheradmand et al. (2014) also found 
NS to have antimicrobial action against Candida albicans and Pseudomonas aeruginosa. Shakibaie et al. (2015) found antibacterial actions of NS against Proteus mirabilis, also in agreement with the current results. The current study provided clear evidence for NS supplementation facilitating tissue and cellular protective influences against environmental stresses.

The photomicrographs of the liver, heart, spleen, and bursa of Fabricius in broiler breeds that were supplemented with NS in their drinking water revealed minimal deviations in the tissue architecture owing to selenium supplementation. However, the Ross broilers exhibited greater adverse effects than Arbor broilers that were supplied with the same dose of traditional commercial Se. These results were inconsistent with those of Alkhudhayri et al. (2018), who reported significant and improved histological outcomes from NS supplementation in the face of environmental challenges and infection. Mousa and Ali (2018) studied the influence of nano-boron on the liver of African ostrich chicks after E. coli infection and observed the ability of nano-particles to reduce the stress factors with increased resistance.

Nano-selenium supplement relieved the negative influence of heat stress, as shorter duration and smaller frequency of TI was obtained. These findings agreed with those of Sarica and Ozdemir (2018), who reported that $\mathrm{TI}$ duration in quail exposed to heat stress at $34^{\circ} \mathrm{C}$ was shortened significantly after feeding diets that contained organic Se with tocopherol acetate or oleuropein, and suggested that NS could mitigate the effect of heat stress on poultry in tropical areas. Broilers exhibit an enhanced behavioral profile in the presence of heat stress, which reflects an improvement of ingestive behaviour when they were supplemented with NS. These findings agreed with those of Fischer et al. (2008), who reported that Se deficiency caused loss of appetite and reduced efficiency of feed utilization. Behavioral enhancement extended to the activity and alertness of broilers as reflected in their walking more and standing or resting less. Chadio et al. (2006) also reported that Se deficiency in animals is characterized by low circulating levels of thyroid hormones that modify activity.

\section{Conclusions}

Supplementing broilers' drinking water with NS rather than inorganic commercial selenium resulted in improvements of productive performance, antioxidant activity, immunoglobulin serum concentrations, biochemical profile, tissue architecture, and habituation to some environmental stressors, including heat stress in breeds such as Ross and Arbor broilers.

\section{Authors' Contributions}

ESS designed the original experiment, prepared and executed it, analysed the sera samples, and assisted in writing the manuscript. RAH participated in the execution of the experiment, analysed the serum samples, and assisted in writing the manuscript. RTH conducted the histopathological examination, prepared the final photomicrographs, and participated in writing the manuscript. OMAB prepared selenium nanoparticles. AAA participated in the execution of the experiment, the behavioral examination, sample collection, and in writing the manuscript. MSH participated in raising the broilers during the experiment, and in writing the manuscript.

\section{Acknowledgements}

Sincere thanks should be provided to O.M. Abdelmoneim for providing the water-soluble selenium nanoparticles and for Prof. M.A. Sobieh for his direction during the execution of the experiment and help in proofreading the manuscript. Sincere thanks to the staff of community services and the Environmental Development Sector, Faculty of Veterinary Medicine, Suez Canal University, Ismailia, Egypt, for their help in removing all the hindrances during the experiment.

\section{Conflict of Interest Declaration}

The authors declare there is no conflict of interest.

\section{References}

Abudabos, A.M., Alyemni, A.H., Dafalla, Y.M. \& Khan, R.U., 2017. Effect of organic acid blend and Bacillus subtilis alone or in combination on growth traits, blood biochemical and antioxidant status in broilers exposed to Salmonella typhimurium challenge during the starter phase. J. Appl. Anim. Res. 45, 538-542.

Ahmadi, M., Ahmadian, A. \& Seidavi, A.R., 2018. Effect of different levels of nano-selenium on performance, blood parameters, immunity and carcass characteristics of broiler chickens. Poult. Sci. J. 6(1), 99-108.

Alkhudhayri, A.A., Dkhil, M.A. \& Al-Quraishy, S., 2018. Nanoselenium prevents eimeriosis-induced inflammation and regulates mucin gene expression in mice jejunum. Int. J. Nanomedicine, 13, 1993-2003.

American Public Health Association, American Water Works Association, Water Environment Federation, 2012. Standard methods for the examination of water and wastewater. 22th edition. American Water Works Association Publications, Washington DC.

Attia, Y.A., Abdalah, A.A., Zeweil, H.S., Bovera F., Tag El-Din, A.A. \& Araft, M.A., 2010. Effect of inorganic or organic selenium supplementation on productive performance, egg quality and some physiological traits of dual-purpose breeding hens. Czech. J. Anim. Sci. 55, 505-519. 
Attia, Y.A., Al-Harthi, M.A., El-Shafey, A.S., Rehab Y.A. \& Kim, W.K., 2017. Enhancing tolerance of broiler chickens to heat stress by supplementation with vitamin E, vitamin $C$ and/or probiotics. Annals of Anim. Sci. 17 (4), 1-15

Bancroff, J.P., Stevenes, A. \& Turner, D.R., 1990. Theory and practice of histological techniques. 3rd edition. Churchill Livingstone, Edinburgh.

Baylan, M., Canogullari, S., Copur, G. \& Ayasan, T., 2015. Effects of dietary selenium source, storage time and temperature on the quality of quail eggs. 7th Balkan Conf. on Anim. Sci. BALNIMALCON, 3-6 June 2015.

Bolea-Fernandez, E., Balcaen, L., Resano, M. \& Vanhaecke, F., 2017. Overcoming spectral overlap via inductively coupled plasma-tandem mass spectrometry (ICP-MS/MS). A tutorial review. J. Anal. At. Spectrom. 32, 16601679.

Cai, S.J., Wu, C.X., Gong, L.M., Song, T., Wu, H. \& Zhang, L.Y., 2012. Effects of nano-selenium on performance, meat quality, immune function, oxidation resistance and tissue selenium content in broilers. Poult. Sci. 91, 2532-2539.

Cameron, G., Roche, B., Schlund, M.W. \& Dymond, S., 2016. Learned, instructed and observed pathways to fear and avoidance. J. Behav. Ther. Exp. Psychiatry 50, 106-112.

Canoğullari, S., Ayaşan, T., Baylan, M. \& Çopur, G., 2010. The effect of organic and inorganic selenium supplementation on egg production parameters and egg selenium content of laying Japanese quail. Kafkas Ün. Vet. Fak. Dergisi. 16 (5), 743-749.

Chadio, S.E., Kotsampasi, B.M., Menegatos, J.G., Zervas, G.P. \& Kalogiannis, D.G., 2006. Effect of selenium supplementation on thyroid hormone levels and selenoenzyme activities in growing lambs. Biol. Trace Elem. Res. $109,145-154$.

Chand, N.S., Naz Khan, A., Khan, S. \& Khan, R.U., 2014. Performance traits and immune response of broiler chicks treated with zinc and ascorbic acid supplementation during cyclic heat stress. Int. J. Biometeorol. 58, $2153-2157$.

Duan, Y., Fu, W., Wang, S., Ni, Y. \& Zhao, R., 2014. Effects of tonic immobility (TI) and corticosterone (CORT) on energy status and protein metabolism in pectoralis major muscle of broiler chickens. Comp. Biochem. Physiol. A 169, 90-95.

El-Deep, M.H., ljiri, D., Ebeid, T.A. \& Ohtsuka, A., 2016. Effects of dietary nano-selenium supplementation on growth performance, antioxidative status, and immunity in broiler chickens under thermoneutral and high ambient temperature conditions. Japan Poult. Sci. 53, 274-283.

Fischer, J., Bosse, A., Most, E., Mueller, A. \& Pallauf, J., 2008. Selenium requirement of growing male turkeys. Br. Poult. Sci. 49, 583-591.

Gangadoo, S., Stanley, D., Hughes, R.J., Moore, R.J. \& Chapman, J., 2016. Nanoparticles in feed: Progress and prospects in poultry research. Trends Food Sci. Technol. 58, 115-126.

Ghalkhanbaz, M., Shariatmadari F. \& Karimi Torshizi, M.A., 2018. Effects of different levels of trace minerals premix in finisher diets on performance, immune system and meat lipid oxidation of chicken fed barley- or wheat-based diet. J. Appl. Anim. Res. 46, 1, 69-73.

Gorer, S. \& Hodes, G., 1994. Quantum size effects in the study of chemical solution deposition mechanisms of semiconductor films. J. Phys. Chem. 98(20), 5338-5346.

Gu, X.H., Hao, Y. \& Wang, X.L., 2012. Overexpression of heat shock protein 70 and its relationship to intestine under acute heat stress in broilers. 2. Intestinal oxidative stress. Poult. Sci. 91(4), 790-799.

Gulyas, G., Csosz, E., Prokisch, J., Javor, A., Mezes, M., Erdelyi, M., Balogh, K., Janaky, T., Szabo, Z., Simon, A. \& Czegledi, L., 2016. Effect of nano-sized, elemental selenium supplement on the proteome of chicken liver. J. Anim. Phys. Anim. Nutr. 101(3), 502-510.

Kheradmand, E., Rafii, F., Yazdi, M.H., Sepahi, A.A., Shahverdi, A.R. \& Oveisi, M.R., 2014. The antimicrobial effects of selenium nanoparticle-enriched probiotics and their fermented broth against Candida albicans. Daru 22(1), 48.

Kim, S.K. \& Lee, J.H., 2016. Biofilm modeling systems. Korean J. Microbiol. 52(2), 125-139.

Kumbhar, S., Khan, A.Z., Parveen, F., Nizamani, Z.A., Siyal, F.A., El-Hack, M.E.A., Gan, F., Liu, Y., Hamid, M., Nido, S.A. \& Huang, K. 2018. Impacts of selenium and vitamin E supplementation on mRNA of heat shock proteins, selenoproteins and antioxidants in broilers exposed to high temperature. AMB Express 8, 112.

Lara, L.J. \& Rostagno, M.H., 2013. Impact of heat stress on poultry production. Animals, 3(2), 356-369.

Lee, J.M., Chun, H.J., Choi, H.S., Kim, E.S., Seo, Y.S., Jeen, Y.T., Lee, H.S., Um, S.H., Kim, C.H. \& Sul, D., 2017. Selenium administration attenuates 5-Flurouracil-induced intestinal mucositis. Nutr. Cancer 69(4), 616-622.

Lei, X., 2017. Avian selenogenome: Response to dietary Se and protection against oxidative insults. Poult. Sci. 96 (Esupplement 1), 220.

Li, M., Wu, J. \& Chen, Z., 2015. Effects of heat stress on the daily behavior of Wenchang chickens. Brazilian J. Poult. Sci. 17(4), 559-566.

Liao, X., Lu, L., Li, S., Liu, S., Zhang, L., Wang, G., Li, A. \& Luo, X., 2012. Effects of selenium source and level on growth performance, tissue selenium concentrations, antioxidation, and immune functions of heat-stressed broilers. Biol. Trace Elem. Res. 150(1-3), 158-165.

Limaye, A., Yu, R.C., Chou, C.C., Liu, J.R. \& Cheng, K.C., 2018. Protective and detoxifying effects conferred by dietary selenium and curcumin against AFB1-mediated toxicity in livestock: A review. Toxins 10(1), 25.

Markovic, R., Ćirić, J., Drljacic, A., Šefer, D., Jovanovic, D., Milanovic, S., Trbovic, D., Radulovic, S., Baltic, M.Ž. \& Starčević, M., 2018. The effect of dietary selenium-yeast level on glutathione peroxidase activity, tissue selenium content, growth performance, and carcass and meat quality of broilers. Poult. Sci. 97(8), 2861-2870.

Markovic, R., Ćirić, J., Starčević, M., Šefer, D. \& Baltić, MZ., 2018. Effect of selenium source and level in diet on glutathione peroxidase activity, tissue selenium distribution, and growth performance in poultry. Anim. Health Res. Rev. 19(2), 166-176. 
Mohanty, P.P., Panda, N., Swain, R.K., Behura, N.C., Ray, P., Sethi, A.K. \& Panigrahi, S., 2018. A Comparison between organic and inorganic selenium. 1. Effect on body weight, laying performance, hatchability in broiler breeder. Int. J. Current Microbiol. Appl. Sci. 7(5), 173-179.

Mohapatra, P., Swain, R.K., Mishra, S.K., Behera, T., Swain, P., Behura, N.C., Sahoo, G., Sethy, K., Bhol, B.P. \& Dhama, K., 2014. Effects of dietary nano-selenium supplementation on the performance of layer grower birds. Asian J. Anim. Vet. Adv. 9(10), 641-652.

Mousa, D.M. \& Ali, B.H., 2018. Impact of boron and nano-boron on the heterophil/lymphocyte ratio and histopathological changes of liver and kidney in broiler chicken infected with Escherichia coli. Basrah J. Vet. Res. 17(3), 290-306.

Murray, P.R., Rosenthal, K.S. \& Pfaller, M.A., 2015. Medical microbiology, 8th Edition, Elsevier Health Sciences, Philadelphia, PA, USA.

National Research Council (NRC), 1994. Nutrient requirements for poultry. Ninth revised edition. National Research Council, New York.

Peters, R.J., Bouwmeester, H., Gottardo, S., Amenta, V., Arena, M., Brandhoff, P., Marvin, H., Mech, A., Botelho Moniz, F., Quiros Pesudo, L., Rauscher, H., Schoonjans, R., Undas, A., Vettori, M.V., Weigel, S. \& Aschberger, K., 2016. Nanomaterials for products and application in agriculture, feed, and food. Trends in Food Sci. Tech. 54, 155-164.

Safdari-Rostamabad, M., Hosseini-Vashan, S.J., Perai, A.H \& Sarir, H., 2017. Nanoselenium supplementation of heatstressed broilers: Effects on performance, carcass characteristics, blood metabolites, immune response, antioxidant status, and jejunal morphology. Biol. Trace Elem. Res. 178(1), 105-116.

Saleh, A.A., Ragab, M.M., Ahmed, E.A.M., Abudabos, A.M. \& Ebeid, T.A., 2018. Effect of dietary zinc-methionine supplementation on growth performance, nutrient utilization, antioxidative properties and immune response in broiler chickens under high ambient temperature. J. Appl. Anim. Res. 46(1), 820-827.

Sarica, S. \& Ozdemir, D., 2018. The effects of dietary oleuropein and organic selenium supplementation in heat-stressed quails on tonic immobility duration and fluctuating asymmetry. Italian J. Anim. Sci. 17(1), 145-152.

Shabani, A., Noshadian, M., Jamilian, M., Chamani, M., Mohammadi, S. \& Asemi, Z., 2018. The effects of a novel combination of selenium and probiotic on weight loss, glycemic control and markers of cardio-metabolic risk in women with polycystic ovary syndrome. J. Functional Foods 46, 329-334.

Shakibaie, M., Forootanfar, H., Golkari, Y., Mohammadi-Khorsand, T. \& Shakibaie, M.R., 2015. Anti-biofilm activity of biogenic selenium nanoparticles and selenium dioxide against clinical isolates of Staphylococcus aureus, Pseudomonas aeruginosa, and Proteus mirabilis. J. Trace Elements Med. Biol. 29, 235-241.

Sinkalu, V.O., Ayo, J.O., Adelaiye, A.B. \& Hambolu, J.O., 2016. Melatonin modulates tonic immobility and vigilance behavioural responses of broiler chickens to lighting regimens during the hot-dry season. Phys. Behav. 165,195201.

Skalickova, S., Milosavljevic, V., Cihalova, K., Horky, P., Richtera, L. \& Adam, V., 2017. Selenium nanoparticles as a nutritional supplement. Nutr. 33, 83-90.

Soliman, E.S. \& Hassan, R.A., 2017. Evaluation of superphosphate and meta-bisulfide efficiency in litter treatment on productive performance and immunity of broilers exposed to ammonia stress. Adv. Anim. Vet. Sci. 5(6), 253-259.

Soliman, E.S. \& Hassan, R.A., 2019. Impact of lighting color and duration on productive performance and Newcastle disease vaccination efficiency in broiler chickens. Vet. World 12(7), 1052-1059.

Soliman, E.S., Hamad, R.T. \& Ahmed, A., 2017. Prophylactic and immune modulatory influences of Nigella sativa Linn. in broilers exposed to biological challenge. Vet. World 10(12),1447-1455.

Soliman, E.S., Moawed, S.A. \& Ziaan, A.M.G., 2016. Assessing cleaning and disinfection regime in a slaughterhouse against carcasses contamination. Adv. Anim. Vet. Sci. 4(9), 449-457.

Soliman, E.S., Sallam, N.H. \& Abouelhassan, E.M., 2018. Effectiveness of poultry litter amendments on bacterial survival and Eimeria oocyst sporulation. Vet. World 11(8), 1064-1073.

Stanley, D., Geier, M.S., Chen, H., Hughes, R.J. \& Moore, R.J., 2015. Comparison of fecal and cecal microbiotas reveals qualitative similarities but quantitative differences. BMC Microbiol. 15(1),1-11.

Surai, P.F. \& Fisinin, V.I., 2014. Selenium in poultry breeder nutrition: An update. Anim. Feed Sci. Tech. 191,1-15.

Surai, P.F., Kochish, I.I., Fisinin, V.I. \& Velichko, O.A., 2018. Selenium in poultry nutrition: From sodium selenite to organic selenium sources. J. Poult. Sci. 55(2), 79-93.

Villagra, A., Olivas, I., Althaus, R.L., Gomez, E.A., Lainez, M. \& Torres, A.G., 2014. Behavior of broiler chickens in four different substrates: A choice test. Brazilian J. Poult. Sci. 16(1), 67-76.

Wadhwani, S.A., Shedbalkar, U.U., Singh, R. \& Chopade, B.A., 2016. Biogenic selenium nanoparticles: Current status and future prospects. Appl. Microbiol. Biotech. 100, 2555-2566.

Wu, Y.N., Yan, F.F., Hu, J.Y., Chen, H., Tucker, C.M., Green, A.R. \& Cheng, H.W., 2017. The effect of chronic ammonia exposure on acute-phase proteins, immunoglobulin, and cytokines in laying hens. Poult. Sci. 96(6),1524-1530.

Xiao, X., Yuan, D., Wand, Y.X. \& Zhan, X.A., 2016. The protective effects of different sources of maternal selenium on oxidative stressed chick embryo liver. Biol. Trace Elem. Res. 172(1), 201-208.

Yang, Y.R., Meng, F.C., Wang, P., Jiang, Y.B., Yin, Q.Q., Chang, J., Zuo, R.Y., Zheng, Q.H. \& Liu, J.X., 2012. Effect of organic and inorganic selenium supplementation on growth performance, meat quality and antioxidant property of broilers. Afr. J. Biotechnol. 11, 3031-3036.

Yip, J., Liu, L., Wong, K.H., Leung, P.H., Yuen, C.W.M. \& Cheung, M.C., 2014. Investigation of antifungal and antibacterial effects of fabric padded with highly stable selenium nanoparticles. J. Appl. Polymer Sci. 131(17), $40728(1-8)$.

Zhao, L., Sun, L.H., Huang, J.Q., Briens, M., Qi, D.S., Xu, S.W. \& Lei, X.G., 2017. A novel organic selenium compound exerts unique regulation of selenium speciation, selenogenome, and selenoproteins in broiler chicks. J. Nutr. 147, $789-797$. 
Zhao, R., Li, K., Wang, J., Wang, Y., Wu, R. \& Zhan, X., 2018. Effects of different forms and levels of selenomethionine on productive performance and antioxidant status of broiler breeders and its offspring. Biol. Trace Element Res. 1-7. 